\title{
O desejo em várias claves: «A morte de Isolda»
}

\author{
Desire in several keys: «A morte de Isolda»
}

Maria Theresa Abelha Alves ${ }^{1}$

Resumo: 0 poema «A morte de Isolda» combina a sonoridade e o poético e articula polifonicamente o mito genesíaco do conhecimento, o mito medieval do amor-paixão, o drama lírico de Wagner por forma a evidenciar oposições primárias: vida e morte, matéria e espírito, obediência e transgressão, céu e terra. A derradeira ária da ópera Tristan und Isolde apresenta um libreto redundante que serve de substrato ao poema de Jorge de Sena, este que é um produto da escuta inteligente de seu autor, capaz de recriar a música em outra linguagem. Assim o trítono que dá início à ópera, inaugurando-lhe o tema condutor, é reproduzido na primeira imagem do poema, acompanhando-o de estrofe a estrofe. 0 poema é lido como são lidos os mitos e a música, na horizontalidade melódica e na verticalidade dos acordes e arpejos, a fim de evidenciar o processo atrativo que torna a linguagem erótica e o poema herético.

Palavras-Chaves: Música; mito; correlações intersemióticas; amor fatal.

\begin{abstract}
The poem «A morte de Isolda» combines sonority and poetic and polyphonically articulates the genesis myth of knowledge, the medieval myth of love-passion, Wagner's lyrical drama in order to evidence primary opposition: life and death, matter and spirit, obedience and transgression, heaven and earth. The last aria of the opera Tristan und Isolde presents a redundant libretto that serves as a substrate to the poem of Jorge de Sena, which is a product of the intelligent listening of its author, able to recreate the music in another language. Thus the tritone that initiates the opera, inaugurating the conductive theme to him, is reproduced in the first image of the poem, accompanying it from stanza to stanza. The poem is read as myths and music are read, in the melodic horizontality and verticality of the chords and arpeggios, in order to highlight the attractive process that makes the language erotic and the poem heretical.
\end{abstract}

Keywords: Music; myth; semiotic correlations; deadly love.

${ }^{1}$ Faculdade de Letras, Universidade Federal do Rio de Janeiro. 
O poema de Jorge de Sena, «A morte de Isolda», como o próprio autor admitiu, nasceu após a escuta da ária final da ópera Tristão e Isolda, de Wagner. 0 poema não pretende traduzir a música, mas a impressão por ela deixada no ato pessoal da escuta, pois, como o poeta já dissera, em Variações Goldberg: «a música é só música», mas ele também sabe que é no campo subjetivo do ouvinte que se processam configurações e sentidos. O poeta elabora a sua escuta e pensa sobre ela em várias claves. Assim combina a sonoridade e o poético, articulando o mito bíblico do conhecimento e o mito medieval do amor-paixão, a música e o libreto de Wagner, e suas pessoais concepções sobre o amor. $\mathrm{O}$ autor de $A$ arte da música apresenta-se, pois, investido de uma característica musical - a polifonia - pois trabalha, conjuntamente, com diferentes linguagens: a da música, a do mito, a da axiologia. $A$ articulação dessas linguagens se faz mediante correlações cruzadas e coloridas pelas imagens, fomentando o encontro de oposições primárias: vida e morte; matéria e espírito; céu e terra.

A obra de Wagner «corresponde ao desejo de fazer a música retornar ao mito, através da melodia infinita pontuada por motivos condutores» (Wisnik, 1989: 157) e pela «teorização de uma ópera nacional, através dos antigos mitos e das fontes literárias da Idade Média» (Magnani, 1989: 191). A ópera Tristão e Isolda foi baseada na versão poética de Gottfried von
Strassburg ${ }^{2}$ para o mito do desditoso casal cujo amor só encontra solução na morte. Desde o «Prelúdio», ela inaugura um ambiente sonoro propício a simbolizar o caráter letal do mito da paixão maldita. 0 «Prelúdio» é suspensivo, sufocante, tenso, dissonante e, sobretudo, carente do repouso conclusivo. Tal ambiente sonoro se deve ao acorde inicial da ópera, consagrado como o «acorde de Tristão» cujo encadeamento cromático é feito de sucessivos semitons ou de intervalos alterados, levando a musicologia a considerá-lo como um marco da dispersão do sistema tonal (Candé, 1981: 72). É através desse acorde invasivo, envolvente, dionisíaco, amoroso e letal que se articulam e se interpenetram os motivos míticos cavalheirescos e corteses que engendram a ópera (encontro, filtro do amor, luta, transfiguração e morte). 0 «acorde de Tristão» acompanha toda a ópera, pois faz parte do tema utilizado como motivo condutor (leitmotiv), numa tensão recorrente cuja resolução é sempre adiada e que só se resolve na ária final. Talvez seja por isso que as gravações da ária «Liebestod», em geral, se fazem acompanhar do lento e plangente «Prelúdio» ${ }^{3}$ que, a partir do acorde ini-

\footnotetext{
${ }^{2}$ A história medieval de Tristão e Isolda foi contada em várias versões, no século XII, as de Béroul, de Tomás da Inglaterra, de Eilhart von Oberg; no século XIII, a de Gottfried von Strassburg, que não foi concluída e que é baseada na de Tomás da Inglaterra. 3 «Liebestod», amor e morte, era o nome inicial do «Prelúdio», o nome da ária final era «Verklärung», transfiguração. Mais tarde, por influência de Frans Liszt, que compreendeu a íntima relação entre o início e o final, «Liebestod» passou a denominar a derradeira ária de Isolda. Mesmo o autor, Wagner, transformou essas duas partes em uma única peça de concerto,
} 
cial suspensivo e do diálogo dos violoncelos com os oboés, conduz as impressões eróticas e tanáticas que inauguram o tema lascivo e amoroso que percorre toda a ópera, como a insistência do desejo, sempre urgente, mas adiado sempre, e antecipa a morte de amor do final. Esse acorde melódico é o primeiro e o último a ser ouvido, sugerindo uma circularidade que aprisiona o desditoso casal.

O «acorde de Tristão» é um trítono ${ }^{4}$ e, na Idade Média, o trítono era denominado diabolus in musica, porque se singulariza pela instabilidade que proporciona, motivada pela ausência do repouso final. Tal desordem interferente, no contexto antigo, só podia ser considerada diabólica. Para os músicos medievais, o trítono era um ruído que deveria ser evitado porque rasurava a harmonia celeste das esferas. Isso porque ele pontua, de dentro de si mesmo, uma ausência, um vazio. Funcionando como manifestação do desejo, o diabolus in musica do início da ópera vai, ao longo dela, adquirindo outros sentidos, simbolizando o passado amoroso definitivamente perdido, e, também,

executando-as conjuntamente, em 1862, três anos antes da estreia da ópera. Ainda hoje, inúmeras gravações aliam, numa única peça musical, o «Prelúdio» e a ária «Liebestod».

${ }^{4} \mathrm{O}$ «acorde de Tristão» é um acorde de fá meio diminuto, com a terça na oitava acima. Wagner utilizou duas notas enarmônicas para criar este acorde de fá. Em vez de usar as notas fá, dó bemol (si), mi bemol e lá bemol, utilizou as notas fá, si, ré sustenido (mi bemol) e sol sustenido (lá bemol). O que deveria ser a resolução do acorde contraria a harmonia tradicional, porque o próximo acorde é de mi maior com a sétima menor, o que provoca a suspensão e não a resolução do primeiro acorde. o seu incessante devir, como cicatriz sonora a doer no corpo de Isolda, experiência de um tempo que se recusa a passar. Etimologicamente, diabolus é o que se lança através, é o que se coloca no meio, é o que separa, o que corta, o que divide, portanto a opção wagneriana pelo trítono não foi inocente, pois ele, num contínuo deslizante, oscilante e fluido, como ponto de referência e de apoio ao longo da ópera, expressa a potência libidinal, a rebeldia dos sentidos, o vazio da separação.

O mito bíblico da árvore do conhecimento, que associa desejo e saber, e que o poema de Jorge de Sena atualiza, comprova que a concupiscência, vontade de conhecer, é diabólica desde a partida. ${ }^{5} \mathrm{Na}$ ópera de Wagner, o trítono, desenho melódico dionisíaco e marginal, com seus encadeamentos cromáticos repetidos, marca a sinuosidade e o apelo irresistível da carne, vigorando sempre no meio e através de todo ser, constituindo-se como o silvo da serpente demoníaca, o pecado original. Os encadeamentos cromáticos e o deslizamento modulatório do «Prelúdio» tornam problemática a definição tonal e potencializam a expressão dramática, uma vez que é frustrada a constante expectativa de resolução das dissonâncias. São eles que sublinham a crise do amor impossível e a paixão sempre em desassossego do par mítico. As dissonân-

\footnotetext{
${ }^{5}$ É de lembrar que Tristão aparece no segundo círculo da Inferno, lugar reservado aos luxuriosos, na Divina comédia, de Dante.
} 
cias da música do «Prelúdio» antecipam a separação dos amantes, que só na morte se juntam. A ária final, «Liebestod», como o canto dos cisnes, é o canto de morte que encena a ruína do desejo sacrificado, mas que encena também um canto de triunfo ao desejo em estado de resplandecência, canto embevecido pela transfiguração de Tristão.

O primeiro ato do drama musical é passado no navio. Isolda, não querendo sucumbir à atração que lhe despertava Tristão, quer envenená-lo, porém em vez de veneno dá-lhe a beber e bebe também, por engano, o filtro do amor, iniciando o drama de um enlace impossível por contrariar as regras sociais, religiosas e familiares do tempo. $O$ segundo ato se passa durante a noite, nos jardins do castelo do rei Mark, marido de Isolda e tio de Tristão, onde os adúlteros se deixam (ou não) levar pela paixão a que o filtro de amor os condenara. Unidos, os dois cantam celebrando a noite que serve de custódia ao amor. O romance clandestino é descoberto por Mark e por Melot, um cortesão que fere o enamorado a golpes de espada. 0 terceiro ato se passa na praia, nas proximidades do castelo de Tristão, onde ele, sofrendo a dor das feridas e a dor da separação, agoniza e espera a chegada de Isolda para curá-lo através dos poderes mágicos que ela possuía. Emocionado diante da amada, ele arranca as ligaduras que protegiam as feridas e morre nos braços dela. $O$ cadáver do amante se transfigura diante do olhar apaixonado da amada que também transfigurada morre, caindo sobre ele (Mezzanotte, 1980: 249-250).

Essa história é contada no libreto por meio de ressonâncias, de repetições, de simetrias frásicas, de oposições, em constantes e mutantes fluxos combinatórios, numa linguagem poética que reproduz a linguagem do mito e também a linguagem musical, de modo que o que importa está tanto na horizontalidade da sucessão ou melódica ou frasal, mas também na verticalidade do que é ouvido ou lido como simultâneo ou correspondente.

A escuta atenta de Jorge de Sena presta atenção às múltiplas correlações que se engendram, às sintonias, às disparidades. Como ocorre na música, o mito e o libreto também se expressam mediante arpejos, polifonias, ecos, inversões e paralelismo e, por isso mesmo, Lévi-Strauss aproximou a linguagem mítica da linguagem musical, pois ambas exigem reconstrução contínua. Para o antropólogo (2004), Wagner e Debussy são músicos do mito, pois «codificam suas mensagens a partir de elementos que já pertencem à ordem do relato» (p. 50) ${ }^{6}$. O mesmo procedimento que atua no cruzamento da sucessão e do simultâneo se reproduz em «A morte de Isolda», poema rico também em ecos, homologias e contrastes.

\footnotetext{
${ }^{6} \mathrm{Cf}$. Mitológicas, principalmente o primeiro volume, Le cru et le cuit, em que o antropólogo, mediante os termos musicais, variações, sonata e fuga, cria seus interlocutores: Wagner, considerado compositor dos mitos, Beethoven, compositor da mensagem e Bach, compositor do código.
} 
Tomando o libreto da ária «Liebestod», é possível detectar múltiplas correlações. Há repetições de estruturas frásicas, como as interrogativas (Isolda se dirige aos amigos - à plateia - em perguntas de natureza retórica), há repetições de vocábulos (o adjetivo «suave», por exemplo, aparece no singular três vezes e uma vez no plural), outros vocábulos se repetem mediante sinonímia (por exemplo, os adjetivos que são os atributos do sorriso e do olhar de Tristão, segundo Isolda: «suave», «delicada», e a locução «com ternura», ou os substantivos «ondas» e «vagas», «coração» e «peito», «aroma» e «fragrâncias» e, ainda, os verbos «afogar», «naufragar»), há pleonasmos significativos que se repetem com pequena variação («ascende às alturas», «subindo às alturas»), há correlações anafóricas (o sintagma «Será que eu devo» inicia três frases interrogativas que se sucedem). 0 libreto da ária é rico em modalizações e aliterações que criam ecos internos. Todo esse sistema de redundâncias corresponde à necessidade mítica de duplicação. Por isso «temos de ler o mito mais ou menos como leríamos uma partitura musical, pondo de parte as frases musicais e tentando entender a página inteira» (Lévi-Strauss, 1978: 68). Por meio de reduplicações, Isolda se pergunta se só ela está escutando a melodia que flui em êxtase e que nela se infiltra subindo às alturas. Assim o libreto reproduz em letra a melodia infinda da ópera.
As perguntas retóricas lançadas por Isolda aos amigos (ou à plateia) a respeito da melodia que só ela ouve são respondidas no poema «A morte de Isolda». Essa música é o apelo libidinoso e tentador da «serpente eterna», é o desejo de conhecer no sentido bíblico, conhecer pelo ato sexual. Alguns vocábulos do libreto final da ária «Liebestod» são retomados pelo poema de Jorge de Sena, que conhecia bem todas as versões do mito medieval do amor-paixão, conhecia bem a melodia e o libreto da ópera Tristão e Isolda ${ }^{7}$, conhecia a interpretação medieval para o trítono e então associou o poder inquietante e sedutor do diabolus in musica à sedução da serpente genesíaca, «serpente eterna», mito bíblico que, através de um eufemismo - conhecimento do bem e do mal - explica a pulsão erótica, o pecado original. O poeta de «A morte de Isolda», apreciador das artes plásticas, sabia como o mito geneíaco do conhecimento do bem e do mal foi interpretado pelos pintores que, em geral, imaginaram o casal bíblico ao lado de uma grande árvore em cujo tronco se enrolava a serpente demoníaca e tentadora enquanto a mulher, que já experimentara o doce fruto proibido, o oferecia ao homem. A cena assim interpretada é tautológica, mas o mito sempre admite uma interpretação alegórica e os poetas sabem disso: a árvore do bem e do

\footnotetext{
7 Sena fez uma versão poética do libreto de Tristão e Isolda para o português.
} 
mal é o mundo, o fruto proibido é o sexo, a serpente é o demônio do desejo. ${ }^{8}$

Todos esses fios se trançam no poema «A morte de Isolda», mediante analogias. Assim o «tecido vivo» se enrola ao redor do mundo como a serpente bíblica se enrola na árvore da ciência do bem e do mal, como o acorde inicial da música de Wagner se vai enrolando em torno de personagens e temas da ópera, circulando tudo. Os diferentes fios se trançam através de comparações (por exemplo, «como um longo sexo»), de modalizações («viscosamente», «ansiosamente»), ou da acentuada preferência por verbos de ação, tais como os verbos «arfar», «palpitar», «enrolar», «penetrar», «estrangular», conjugados em diferentes tempos e modos.

A música se apresenta no poema, objetiva e tecnicamente, através de um léxico que lhe é próprio, «crescendos», «balanço», «harmônico», «ruídos e estridências», «silêncio». O espectro das alturas melódicas constitui a tessitura musical, daí o poeta representá-lo no primeiro verso do poema: «Nesta fluidez contínua de um tecido vivo», porque os corpos sonoros vibram e se propagam. Há som, ruído, pulso e silêncio na música recuperados pelo poema quando, respectivamente, alude ao

\footnotetext{
${ }^{8}$ Para Philon e para Clemente de Alexandria, a falta genesíaca estava ligada à descoberta da sexualidade. Embora oficialmente a Igreja não tenha admitido tal interpretação, a tradição a considera do mesmo modo (cf. Bechtel, 2000: 39).
}

«balanço longamente harmônico», aos «roncos e estridências», ao palpitar da frustração, ao «silêncio imóvel».

Mas a música também é sugerida por questões eminentemente poéticas, como os cavalgamentos, as aliterações, as repetições, os ecos e as pausas. 0 poema é composto por 34 versos e apenas 4 deles não estão cavalgados. A utilização ostensiva do enjambement, que sintaticamente une um verso a outro e ao seguinte, sucessiva e interminavelmente, foi a opção poética para simbolizar o tema condutor da ópera, seu sedutor acorde irresoluto que se propaga em emissões pulsantes sonoras e corporais.

O poema apresenta vocábulos que ecoam em outros, fomentando rimas internas, tal é o caso das modalizações com os advérbios terminados em -mente; «viscosamente», «ansiosamente», «largamente»; engendram aliterações que propagam um sibilino som, a condizer com o silvo-sopro da «serpente eterna».

Já que retoma um mito medieval, o poeta exercita seu labor mediante alguns processos poéticos da lírica trovadoresca, pelo enjambement ata até ao fim dos versos, reproduzindo a um só tempo a melodia infinita wagneriana e o processo de ata-finda medieval; recorre a repetições de vocábulos em consonância com o dobre e com o mosdobre da «arte de trovar», fomentando ecos e rimas internas que reforçam a musicalidade do poema. 
A harmonia musical ensina que as pausas podem sugerir o prolongamento da nota que as antecede. 0 poema apresenta pontos finais nos versos 10,18, 23, 28, 29, e 34. Pensando o poema pela clave musical, tais pausas são silêncios significativos que prolongam linhas de força do poema: o amor mítico, fruto do acaso, pois «de um filtro só nasceu»; o amor romântico que, por ser idealizado, «é cópula mental»; e que, por isso mesmo, não pode experimentar «o esgotamento da chegada que só ternura torna simultânea»; a esterilidade dos que não sucumbiram ao apelo do desejo, porque para eles se tornou estéril «o sopro da serpente eterna»; a piedade do eu-Lírico do poema «Fica-nos o gosto da piedade», por aqueles que não experimentaram «um amor de vida». As pausas acentuam as oposições e as homologias que se engendram no poema: de um lado, amor-morte-alto ou céu (amor mítico e romântico em que a morte sublima e sacraliza os amantes; no libreto, Tristão se transfigura); de outro, amor-vida-baixo ou terra (amor consumado em ternura e cumplicidade dos amantes que se entregaram ao apelo dos sentidos e para quem o sopro da serpente eterna não foi estéril). 0 primeiro é o amor mítico que o romantismo retomou e que alimenta o libreto wagneriano. O segundo é o amor reivindicado pelo eu-lírico do poema, amor concorde com a filosofia amorosa do poeta para quem abstrair o corpo, negar seus apelos, não se deixar seduzir pela linguagem dos afetos é que constitui o grande delito, o verdadeiro pecado original. Com esta oposição de base, o poema parece refletir a textura contrapontística da ópera.

A seleção vocabular de "A morte de Isolda» cria universos de significação tanto na horizontalidade, pelos encadeamentos sintáticos, como também na verticalidade, pela multiplicidade semântica que um mesmo vocábulo adquire ao longo do poema e, então, se dá a ler como a ler se dão a música e o mito. A expressão «tecido vivo», por exemplo, contempla a melodia da ária «Liebestod», a pulsão erótica, e a representação metafórica dela: a «serpente eterna» que circula o mundo, circula os amantes, circula o amor, num movimento contínuo que evolui em direção a seu retorno, fim que gera recomeço. Tal «tecido vivo»é imagem fecunda do ouroboros (cf. Chevalier e Gheebrant, 1974a; 1974b), a serpente que morde sua cauda, fechando-se sobre si mesma, tal como a própria música infinita da ópera de Wagner, tal como o poema de Jorge de Sena, que, ao mesmo tempo, evolui e se amarra ao início, pelos cavalgamentos. Como imagem do desejo, «tecido vivo» é expressão homóloga de uma outra: «chama ambígua». Porque sempre ativo e contínuo, nada melhor para expressar o desejo que os verbos de ação no gerúndio. Ele «se distende arfando», «se enrolando em torno ao mundo», ouroboros cósmico que simboliza o psiquismo tanto obscuro como vivificante e que, por isso mesmo, com seus anéis, encerra o mundo, na música de Wagner e no poema de Sena, unindo a Terra (a serpente, os 
amantes) ao Céu (a transfiguração em Wagner e o «amor de vida» em Sena), o masculino ao feminino, o começo ao fim, compondo, a um só tempo, similaridades e contrastes. ${ }^{9}$

A polaridade manifesta no poema entre concepções díspares de amor é sintetizada pelo verbo de ação penetrar,que possui considerável significação sexual. No primeiro caso, o desejo «não penetra», «estrangula»; no segundo, «os sexos se demoram penetrados». No primeiro caso, o desejo «estrangulado» é «morte impenetrável», tem potência destruidora para os amantes: «dois seres que o sexo destruiu»; no segundo, a potência erótica é apaziguadora: «paz dos rostos que se pousam».

Esse «amor de vida» é concebido pelo eu-lírico como alternativa para o amor de morte do mito bíblico e também para o amor letal do mito do amor-paixão. 0 mito bíblico considera o amor pecaminoso e, por isso, condena o casal genesíaco à expulsão do paraíso, ao reconhecimento da própria nudez, às dores e à morte. $\mathrm{O}$ amor letal do mito do amor-paixão, ao longo dos anos, tem alimentado a concepção ocidental através da inevitável rima: amor e dor, exacerbada no romantismo que alimenta a ópera wagneriana. Contra um e outro mortífero amor, insere-se no poema, até

\footnotetext{
${ }^{9}$ A associação da imagem seniana da «serpente etern» ao símbolo do ouroboros já se fez com muita propriedade no artigo de Francisco Cota Fagundes, «Do amor na poesia de Jorge de Sena: "A morte de Isolda"» revisitada.
}

mesmo nos versos que o pretendem negar, a chama viva do amor compartilhado.

Assim, a primeira estrofe, composta por 18 versos, reflete, na horizontalidade, a irresolução do desejo apenas mental, e, na verticalidade, a explosão sensual, através de verbos como «arfando», «enrolando», «palpita», «exaspera» e «expira», de advérbios como «viscosamente», «ansiosamente», de substantivos como «sexo», «chama», «gozo», «prazer», «balanço», «poses», «cópula», de adjetivos como «vivo», «longo», «húmidos», «doce», «delirantes», que simbolizam etapas não de uma «cópula mental», mas de uma efetiva conjunção corpórea, «fluidez sem tempo» da ânsia ao êxtase.

Já a segunda estrofe, contrapõe ao amor fatal o amor de ternura compartilhada que deixa apaziguados os amantes, «enquanto os sexos se demoram penetrados no puro e tão tranquilo esgotamento da chegada», porém é precisamente deste amor que o par mítico e wagneriano carece. $O$ contraponto da segunda estrofe inverte os eixos da primeira. Nesta, a horizontalidade expõe a ausência do enlace corpóreo enquanto a verticalidade evidencia sua sinuosa presença; na segunda, dá-se precisamente o contrário, pois Tristão e Isolda não vivenciam o «tranquilo esgotamento da chegada».

$\mathrm{Na}$ terceira estrofe, a enunciação emerge propondo uma síntese que retoma o mito do amor-paixão, completando o que o poeta 
medieval que inspirou Wagner deixara incompleto: «Fica-nos o gosto da piedade. E uma vontade de enterrá-los juntos pra que talvez na morte - imaginada - se conheçam melhor do que se amaram». Conta o mito que Tristão e Isolda foram enterrados separadamente e sobre cada túmulo foi plantada uma árvore. As árvores cresceram e seus ramos se entrelaçaram, num estreito abraço, a simbolizar que, finalmente, eles se conheceram, no sentido bíblico, comeram o fruto proibido na eternidade.

O mito do amor-paixão é um mito herético, pois se, de um lado, reproduz as regras do grupo em que foi gerado, em que o adultério é punido como maldito e diabólico, condenando os amantes à separação e à morte, de outro, contradiz as regras sociais e espirituais do tempo ao fazer a conjunção dos amantes depois da morte através do símbolo das árvores entrelaçadas, sacralizando eternamente os infratores.

Na ópera, tal beatificação do maldito se processa mediante a transfiguração de Tristão no Tabor do palco wagneriano. 0 músico, dessa maneira, santifica o pacto com o Diabo, inocenta o delito, perdoa o pecado original. 0 poema de Jorge de Sena hipertrofia a heresia salutar de suas fontes, pois o fruto proibido perde sua conotação mortífera. O poema ilumina a positiva errância do desejo, a sua absoluta identidade e concretude, a sua ubiquidade infinita, definitiva aposta no imponderável, no desvio das normas. Tudo se relativiza quando se articulam oposições que trocam os valores e os sentidos se multiplicam. Como glosa requintada e deslocada, Sena simplesmente não cita, parodia. Seu canto paralelo desnorteia os dogmas sócio-religiosos que servem de substrato aos mitos e à ária «Liebestod», evidenciando que desejo, sexo, erotismo estão além do bem e do mal, fora da precariedade da doxa. A revisitação dos mitos e da ópera efetuada pelo poeta português admite que «a infração à Lei é condição primeira da exaltação amorosa» (Kristeva, 1983: 226) ou que, indo dar ao mesmo, sucumbir ao silvo-sopro da serpente é a senha para entrar na vida. 0 amor reivindicado pelo poema se alimenta do fruto proibido, é fora da Lei, é um ético pacto com o Diabo.

\section{Bibliografia}

\section{Impressa}

Bechtel, G. (2000). Les quatre femmes de Dieu. Plon. Paris;

Candé, R. (1981). Wagner. Em: Historia universal de la música. (Trad. de Juan Novella Domingo). Aguilar. Madrid. Vol. 2. pp. 70-75;

Chevalier, J. e Gheerbrant, A. (1974a). Ouroboros. Em: Dictionnaire des symboles: Mythes, rêves, coutumes, gestes, formes, figures, couleurs, nombres. Seghers. Paris. Vol. 3. pp. 339-340;

Chevalier, J. e Gheerbrant, A. (1974b). Serpent. Em: Dictionnaire des symboles: Mythes, rêves, coutumes, gestes, formes, figures, couleurs, nombres. Seghers. Paris. Vol. 4. pp. 183-198;

Kristeva,J. (1983). Histoires d'amour. Denoël. Paris; Lévi-Strauss, C. (1978). Mito e significado. (Trad. de António Marques Bessa). Edições 70. Lisboa; 
Lévi-Strauss, C. (2004). Mitológicas: O cru e o cozido. (Trad. de Beatriz Perrone-Moisés). Cosac \& Naify. São Paulo. Vol. 1;

Magnani, S. (1989). A reforma wagneriana. Em: Expressão e comunicação na linguagem da música. Editora da UFMG. Belo Horizonte;

Mezzanotte, R. (1979). Tristan und Isolde. Em: La opera: Enciclopédia del arte lírico. (Trad. de Juan Novella Domingo). Aguilar. Madrid. pp. 249-251;

Sena, J. de. (1968). Arte de música: Trinta e duas metamorfoses musicais e um prelúdio, seguidos de um pot-pourri. Moraes Editores. Lisboa;
Wisnik, L.M. (1989). O som e o sentido. Cia. das Letras. São Paulo.

\section{Digital}

Fagundes, F.C. (2007). Do amor na poesia de Jorge de Sena: «A morte de Isolda» revisitada [Versão electrônica]. Em: F.C. Fagundes e I.M.F. Blayer (coords.). Tradições portuguesas/Portuguese traditions. In honor of Claude L. Hulet. Portuguese Heritage Publications of California. San Jose, CA. Acedido a 12 de dezembro de 2018, em https://works.bepress.com/francisco_fagundes/28. 